\title{
Antioxidative responses of cell suspension cultures of two Coffea arabica varieties to low aluminum levels at pH 5.8
}

\author{
Alexandra Bottcher ${ }^{1}$, Paula Macedo Nobile ${ }^{1,2}$, Paula Fabiane Martins ${ }^{3}$, Fábio Frangiotti Conte ${ }^{4}$, Ricardo \\ Antunes Azevedo ${ }^{3}$ and Paulo Mazzafera ${ }^{1,5}$
}

Received: 29.09.2011; accepted: 2.02.2012

\begin{abstract}
Antioxidative responses of cell suspension cultures of two Coffea arabica varieties to low aluminum levels at $\mathrm{pH}$ 5.8). The effects of aluminum (Al) on the activities of antioxidant enzymes and ferritin expression were studied in cell suspension cultures of two varieties of Coffea arabica, Mundo Novo and Icatu, in medium with $\mathrm{pH}$ at 5.8. The cells were incubated with $300 \mu \mathrm{M} \mathrm{Al}^{3+}$, and the $\mathrm{Al}$ speciation as $\mathrm{Al}^{3+}$ was $1.45 \%$ of the mole fraction. The activities of superoxide dismutase (SOD), catalase (CAT), and glutathione S-transferase (GST) were increased in Mundo Novo, whereas glutathione reductase (GR) and guaiacol peroxidase (GPOX) activities remained unchanged. SOD, GR, and GST activities were increased in Icatu, while CAT activity was not changed, and GPOX activity decreased. The expression of two ferritin genes (CaFer 1 and $\mathrm{CaFer2}$ ) were analyzed by Real-Time PCR. Al caused a downregulation of CaFER1 expression and no changes of CaFER2 expression in both varieties. The Western blot showed no alteration in ferritin protein levels in Mundo Novo and a decrease in Icatu. The differential enzymes responses indicate that the response to $\mathrm{Al}$ is variety-dependent.

Key words: aluminum toxicity, antioxidant enzymes, ferritin, oxidative stress
\end{abstract}

RESUMO - (Resposta antioxidante de células em suspensão de duas variedades de Coffea arabica submetidas à baixa concentração de alumínio em pH 5.8). Foram estudadas a atividade de enzimas antioxidantes e a expressão da ferritina em culturas celulares de duas variedades de Coffea arabica, Mundo Novo e Icatu, tratadas com alumínio (Al) em meio de cultura com pH 5.8. As células foram incubadas com $300 \mu \mathrm{M} \mathrm{Al}^{3+}$, e a especiação do $\mathrm{Al}$ para $\mathrm{Al}^{3+}$ foi de $1.45 \%$. Para Mundo Novo, a atividade da superóxido dismutase (SOD), catalase (CAT) e glutationa S-transferase (GST) aumentou, enquanto que a atividade da glutationa redutase (GR) e da guaiacol peroxidase (GPOX) permaneceu inalterada. Para Icatu, a atividade da SOD, GR e GST aumentou, a atividade da CAT não se alterou e da GPOX diminuiu. Foram analisadas a expressão de dois transcritos da ferritina ( $\mathrm{CaFer} 1$ e CaFer2) por meio de PCR em Tempo Real. O Al provocou queda na expressão do CaFER1 e nenhuma alteração em CaFER 2 nas duas variedades. Não houve alteração no acúmulo de ferritina para Mundo Novo, mas uma diminuição para Icatu. A resposta diferencial das enzimas indica que a resposta antioxidante é variedade dependente. Palavras-chave: enzima antioxidante, estresse oxidativo, ferritina, toxicidade do alumínio

\section{Introduction}

Many types of abiotic and biotic stresses induce the formation of reactive oxygen species (ROS) in plant cells (Boscolo et al. 2003). ROS are potentially dangerous molecules, whose production must be finely controlled in cells as they have a remarkable capacity to cause dramatic physiological damage
(Gratão et al. 2005). However, the biosynthesis of ROS molecules cannot be completely eliminated due to their functions as signalling molecules, being important parts of plant defence against abiotic and biotic stresses (Strozycki et al. 2003, Gratão et al. 2005, ).

To minimise the damaging effects of ROS, plant cells possess protection systems based on

1. Universidade Estadual de Campinas, Departamento de Biologia Vegetal, Instituto de Biologia, Caixa Postal 6109, 13083-970 Campinas, SP, Brazil

2. Instituto Agronômico de Campinas, Centro de Cana, Ribeirão Preto, SP, Brazil

3. Universidade de São Paulo, Departamento de Genética, Escola Superior de Agricultura Luiz de Queiroz, Piracicaba, SP, Brazil

4. Universidade Estadual de Campinas, Departamento de Genética, Evolução e Bioagentes, Instituto de Biologia, Caixa Postal 6109, 13083-970 Campinas, SP, Brazil

5. Corresponding author: pmazza@unicamp.br 
both non-enzymatic and enzymatic antioxidant defences (Scandalios 2005). Glutathione (GSH), cysteine, the hydroquinones, mannitol, vitamins $\mathrm{C}$ and $\mathrm{E}$, the flavonoids, some alkaloids, and $\beta$-carotene are examples of non-enzymatic defences, while enzymatic antioxidant defences include enzymes such as catalase, peroxidases and dismutases, and enzymes of the ascorbate-glutathione cycle, among others (Azevedo et al. 1998, Scandalios 2005). Both non-enzymatic and enzymatic antioxidant defences work to efficiently reduce excess ROS production under normal conditions, and without them, the toxic oxygen species can have harmful effects, such as lipid peroxidation and protein and DNA oxidation, leading, in many cases, to cell death (Boscolo et al. 2003, Strozycki et al. 2003).

Aluminum (Al) is not a transition metal and cannot catalyze redox reactions; however, the $\mathrm{Al}^{3+}$, the most toxic of the soluble forms of $\mathrm{Al}$, is involvement in the induction of oxidative stress in many plant species (Yamamoto et al. 2003). In general, for soils with $\mathrm{pH}>5.5, \mathrm{Al}$ concentration is lower than $37 \mu \mathrm{M}$, but with the $\mathrm{pH}$ decreases $\mathrm{Al}$ is released into soil solution (Ramírez-Benítez et al. 2008). Al is the major growth-limiting factor for plants on acid soils, and at micromolar concentrations it can inhibit plant root growth (Kochian et al. 2002). Due these aspects, Al toxicity is becoming an economically important issue, because acid soil comprise up $70 \%$ of the world's arable lands, limiting the growth of important food crops and causing severe food losses (Kochian et al. 2002, Chen et al. 2010). The major recognised symptom of Al toxicity is the inhibition of root growth, but it can also provoke a reduction in respiration and ATP synthesis (Delhaize \& Ryan 1995, Yamamoto et al. 2003).

Some plant species and cultivars have developed tolerance strategies to Al toxicity, as increasing the antioxidant enzymes activities and changing the expression of various genes induced by Al presence (Pereira et al. 2011). Al induces the expression of genes that have already been characterised in wheat, maize, sugarcane, tobacco and Arabidopsis (Simonovicova et al. 2004, Pereira et al. 2011). Richards et al. (1998) observed high levels of peroxidase (PER) mRNA in A. thaliana exposed to Al during $48 \mathrm{~h}\left(50 \mu \mathrm{m} \mathrm{Al}{ }^{3+}\right)$, and low of glutathione S-transferase (GST) and superoxide dismutase (SOD) mRNAs. In the same study, catalase (CAT) mRNA declined during Al stress. In tobacco cells it was also observed that the activities of peroxidases are induced by Al stress (Ezaki et al. 1996). Pea plants (Pisum sativum L.) submitted to Al treatment had an increase of genes encoding the enzymes GST, CAT, SOD, and ascorbate peroxidase (Panda \& Matsumoto 2010). Several other genes are induced by $\mathrm{Al}$ but in general they are related stress responses, like oxidative stress, pathogen infection, heat shock, metal stress, and hormone treatment (Ezaki et al. 2001).

Ferritin is a protein found in all the living kingdom, except in yeast, that can store up to 4,500 iron (Fe) atoms in their central cavities (Briat et al. 2010b). In animal cells, ferritin is involved in the response against stresses resulting from ultraviolet irradiation, phorone (a glutathione-depleting drug), and excess iron (Vile \& Tyrrell 1993, Cairo et al. 1995, Déak et al. 1999). In plants, ferritin gene expression seems be modulated by different environmental factors, and many reports have suggested that it plays an important role in protecting cells against oxidative stress (Ravet et al. 2009, Briat et al. 2010b). The iron excess results to an increase in ROS, provoking oxidative stress. The synthesis of ferritin is induced by iron, $\mathrm{H}_{2} \mathrm{O}_{2}$, NO or ozone application, and high light intensity, and antagonized by antioxidant molecules (Briat et al. 2010a).

Coffea is the most economically important genus of Rubiaceae family and is a very important crop in several tropical countries (Ramírez-Benítez et al. 2009). In Brazil, one of the largest coffee exporter in the world, $40 \%$ of coffee plantations are established in soils with low $\mathrm{pH}$ (3.7 to 5.0), with high Al content (Rodrigues et al. 2011). Although Al toxicity is a problem for coffee-producing countries, there are only a few reports about tolerance and susceptibility of coffee plantations to high Al concentration in soil or nutrient solution (Pavan \& Bingham 1982, Rodrigues et al. 2011). Some recent studies reported that soil superficial layer corrected with lime and fertilizers allows the normal growth of aerial parts of coffee tree cultivated in Al-rich subsoils, although had affected root distribution with depth (Rodrigues et al. 2011). Ramírez-Benítez et al. (2008) have analyzed the induction of organic acids in C. arabica cells treated with $100 \mu \mathrm{M} \mathrm{AlCl}_{3}$, these organic compounds are considered to be a major factor in plant Al resistance. Pinheiro et al. (2004) have studied the roles of antioxidant enzymes in coffee plants in response to drought, but no study has been carried out trying to establish a relationship between Al toxicity, ferritin induction, and the mechanisms of antioxidant defense in this crop. 
For many reports of Al toxicity and plant antioxidant responses, highly stress-inducing metal concentrations are used, and consequently, significant metabolic changes are a rule. For most of crops, the maintenance of a soil $\mathrm{pH}$ ranging from 5 to 6 is recommended, but even at this $\mathrm{pH}$, soluble toxic $\mathrm{Al}$ may still be available in very low concentrations. Therefore, the aim of this work was to study the effects of low $\mathrm{Al}$ concentrations on the enzyme antioxidant system, including ferritin, in coffee cell suspension cultures. Because we wanted to isolate the effects of $\mathrm{Al}$ from low $\mathrm{pH}$ soil, the medium $\mathrm{pH}$ was kept at 5.8, and the $\mathrm{Al}$ concentration was increased to a level $\left(300 \mu \mathrm{M} \mathrm{Al}^{3+}\right)$ that was higher than the dose used in the literature for $\mathrm{pH} 4.3\left(200 \mu \mathrm{M} \mathrm{AlCl}^{3}\right)$ (Ramírez-Benítez et al. 2009).

\section{Material and methods}

Coffee cell suspension culture - Leaves of the third and fourth leaf pairs of Coffea arabica L. var. Mundo Novo (IAC 388-1) and the tolerant hybrid Icatu (IAC 404-5; C. arabica $\times$ C. canephora) were used to produce the cell cultures. These varieties are widely cultivated in Brazil. Icatu was included in this study because, although not confirmed in several field trials, it has been suggested as an Altolerant variety (Rodrigues et al. 2011). The explants were maintained in CIM (callus inducing medium) solid medium (Neuenschwander \& Baumann 1992) containing MS salts (Murashige \& Skoog 1962) at pH 5.8 and supplemented with $10 \mathrm{mg} \mathrm{L}^{-1}$ thiamine$\mathrm{HCl}, 100 \mathrm{mg} \mathrm{L}^{-1}$ inositol, $30 \mathrm{~g} \mathrm{~L}^{-1}$ sucrose, $4 \mathrm{mg} \mathrm{L}^{-1}$ kinetin and $1 \mathrm{mg} \mathrm{L}^{-1} 2,4-\mathrm{D}$. Calluses that were produced in 12-13 weeks in the dark and presented with a pale-yellow colour and a friable aspect were desegregated, transferred to $30 \mathrm{ml}$ of liquid CIM medium in a $250 \mathrm{ml}$ Erlenmeyer flasks and maintained at $100 \mathrm{rpm}$ in the dark at $25 \pm 2{ }^{\circ} \mathrm{C}$. Every week, half of the cells from the flask were transferred to a new flask containing $15 \mathrm{ml}$ of fresh CIM medium. At this stage, a forceps was used to eliminate large aggregates to obtain uniform cell suspensions formed by small homogeneous aggregates.

Aluminium cell treatments - To induce Al stress, seven-day-old coffee suspension cells were suction-dried, and approximately $4 \mathrm{~g}$ of cells were weighed and transferred to a new flask, containing $50 \mathrm{ml}$ of fresh liquid CIM medium with or without $300 \mu \mathrm{M} \mathrm{Al}^{3+}$ as $\mathrm{AlK}\left(\mathrm{SO}_{4}\right)_{2} \cdot 12 \mathrm{H}_{2} \mathrm{O}$. The flasks were incubated for $72 \mathrm{~h}\left(100 \mathrm{rpm}\right.$ in the dark at $\left.25 \pm 2{ }^{\circ} \mathrm{C}\right)$, and the cells were harvested by vacuum filtration on filter paper, washed with $100 \mathrm{~mL}$ of $500 \mathrm{mM}$ $\mathrm{NaCl}$ to remove any loosely associated $\mathrm{Al}$ and then washed with abundant distilled deionised water. Washed cells were immediately frozen in liquid nitrogen and stored at $-80{ }^{\circ} \mathrm{C}$ for further analyses. Small portions of the cells were freeze-dried for lipid peroxidation determinations. Previous results have shown that under the cultivation conditions used here, seven-day-old coffee cells are in the exponential growth phase (Filippi et al. 2007).

Aluminium concentration in the cells - The cells were harvested by filtration, washed with $500 \mathrm{mM}$ $\mathrm{NaCl}$ (to desorb $\mathrm{Al}$ trapped in the cell walls) and distilled water, dried $\left(60{ }^{\circ} \mathrm{C}\right.$ for $\left.76 \mathrm{~h}\right)$, weighed and ground to a powder in a mortar with a pestle. Al concentrations were determined by inductively coupled plasma-optical emission spectroscopy (ICP-OES; JobinYvon, JY50P) after $\mathrm{HNO}_{3}-\mathrm{HClO}_{4}$ digestion. To obtain an estimate of the free $\mathrm{Al}^{3+}$ in the medium, we used the Geochem software (http://www. plantmineralnutrition.net/Geochem/Geochem $\% 20$ Download.htm), applying only the information regarding the mineral composition.

Real-Time PCR Analyses of ferritin genes - RNA extraction, cDNA synthesis and quantitative real-time PCR analysis of CaFERl (GenBank GQ913984) and CaFER2 (GenBank GU001880) were carried out essentially as described by Bottcher et al. (2011). Ribosomal protein rpl39 was used as an endogenous control. Three technical replicates were obtained for each of three biological replicates of each sample and PCR reactions in the absence of template were also performed as negative controls for each primer pair. Data were analyzed using the threshold cycle $(\mathrm{Ct})$, which is the fractional cycle number at which a fixed amount of DNA is formed. The relative gene expression was presented using $2^{-\Delta \Delta \mathrm{Ct}}$ method (Livak \& Schmittgen 2001).

Total protein extraction and Western blot analysis The coffee cells harvested by filtration were subjected to total protein extraction. Initially, the cells were homogenised in $5 \mathrm{ml} 100 \mathrm{mM}$ HEPES ( $\mathrm{pH}$ 7.0), $2 \mathrm{mM}$ EDTA, $5 \mathrm{mM} \mathrm{MgCl}, 2 \%$ ascorbic acid and $10 \mathrm{mM}$ 2-mercaptoethanol. The homogenate was incubated for $30 \mathrm{~min}$ on ice and then centrifuged 
$\left(27,000 \times g\right.$ for 25 min at $\left.4{ }^{\circ} \mathrm{C}\right)$, and the supernatant was filtered in a PD10 Sephadex G25 column (Amersham Biosciences). The proteins were eluted with $20 \mathrm{mM}$ HEPES (pH 7.0), and the total soluble protein was quantified (Bradford 1976), using bovine serum albumin (Sigma) as the standard. The Western blot analysis were carried out essentially as described by Bottcher et al. (2011). The polyclonal anti-ferritin antibody was kindly supplied by Dr. Janette Palma Fett (Universidade Federal do Rio Grande do Sul, Porto Alegre, Brazil). The quantification was carried out by measuring the intensity of the bands in relation to the control, using the ImageJ software (http://rsbweb. nih.gov/ij/).

Enzyme extraction and assays - Samples were extracted as for the Western blot analysis and stored at $-80{ }^{\circ} \mathrm{C}$ until the superoxide dismutase (SOD, EC 1.15.1.1), guaiacol peroxidase (GPOX, EC 1.11.1.7), catalase (CAT, EC 1.11.1.6), glutathione S-transferase (GST, EC 2.5.1.18) and glutathione reductase (GR, EC 1.6.4.2) activity analyses. Total CAT activity was determined as described by Azevedo et al. (1998). SOD, GR and GPOX activities were determined as described by Gomes-Junior et al. (2006a). Activity staining following non-denaturing PAGE was carried out for total SOD activity (Gomes-Junior et al. 2006a). GST activity was determined as described by Habig \& Jakoby (1981).

Lipid peroxidation - Measurements were taken from a $0.25 \mathrm{~g}$ tissue sample, in which the amount of malondialdehyde (MDA) was determined by the thiobarbituric acid-reactive substances (TBARS) (Cakmak \& Horst 1991). The concentration of MDA was calculated, using an extinction coefficient of $155 \mathrm{mmol}^{-1} \mathrm{~cm}^{-1}$.

Statistics - The one-factor analysis of variance (ANOVA) test was used to assess differences in CaFER 1 and CaFER2 gene expression between Al-treated and non-treated cells and to analyse TBARS concentrations and CAT, GR, GPOX and GST activities. When a significant variation was found, the Tukey test was used as a post hoc comparison to adjust the $p$ values. Al accumulation data were expressed as the standard error of the mean $( \pm$ SEM) of three independent replicates. The statistical significance was set to an $\alpha$ level of $5 \%$, and the analysis was carried out with the BioEstat 3.0 program (Ayres et al. 2003).

\section{Results}

Aluminium content in the cells and free $\mathrm{Al}^{3+}$ in the medium - Mundo Novo cells treated with Al accumulated 4,500 $\mathrm{mg} \mathrm{Al} \mathrm{kg}^{-1}$ dry weight, while Icatu accumulated 4,350 $\mathrm{mg} \mathrm{Al} \mathrm{kg}^{-1}$. Al was not detected in the control cells. Free $\mathrm{Al}^{3+}$ in the medium was calculated, using the Geochem software, and it was $1.43 \%$, corresponding to $4.35 \mu \mathrm{M} \mathrm{Al}^{3+}$.

Lipid peroxidation - No statistical differences were observed in lipid peroxidation among Mundo Novo and Icatu control and Al-treated cells. The values ranged from 3.67 to $4.00 \mathrm{nmol} \mathrm{g}^{-1}$ (figure 1).

RT-qPCR and Western blot analyses of ferritin - Al induced a downregulation of CaFERI expression in suspension cells of the varieties Mundo Novo $(p<0.05$, figure $2 \mathrm{~A})$ and Icatu $(p<0.05$, figure $2 \mathrm{~B})$ of $C$. arabica. An approximately five-fold decrease was observed for Mundo Novo and a two-fold decrease for Icatu compared to their respective controls. No significant changes were detected for CaFER2 mRNA levels in Mundo Novo ( $p=0.0582$, figure 2A) and Icatu ( $p=0.7655$, figure 2B). The Western blot analyses did not show alterations in the protein ferritin levels in the Mundo Novo cells (figure 3A), but a decrease of 1.66-fold (relative intensity to the control) was observed in the Icatu cells (figure 3B). Relative abundance of ferritn protein in coffee cells treated with Al was obtained by densitometric analysis.

Enzyme activities - In some ways, the activities of all antioxidant enzymes were altered by $\mathrm{Al}$, and differences were observed between the two coffee

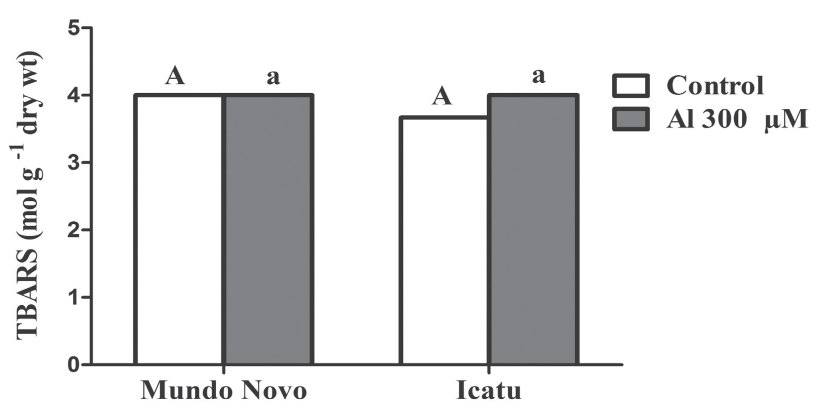

Figure 1. Thiobarbituric acid-reacting substances (TBARS) content in varieties of Mundo Novo and Icatu suspension cells grown for $72 \mathrm{~h}$ with $300 \mu \mathrm{M} \mathrm{Al}$. Means with the same letter are not significantly different $(p<0.05)$ by the Tukey's test. 

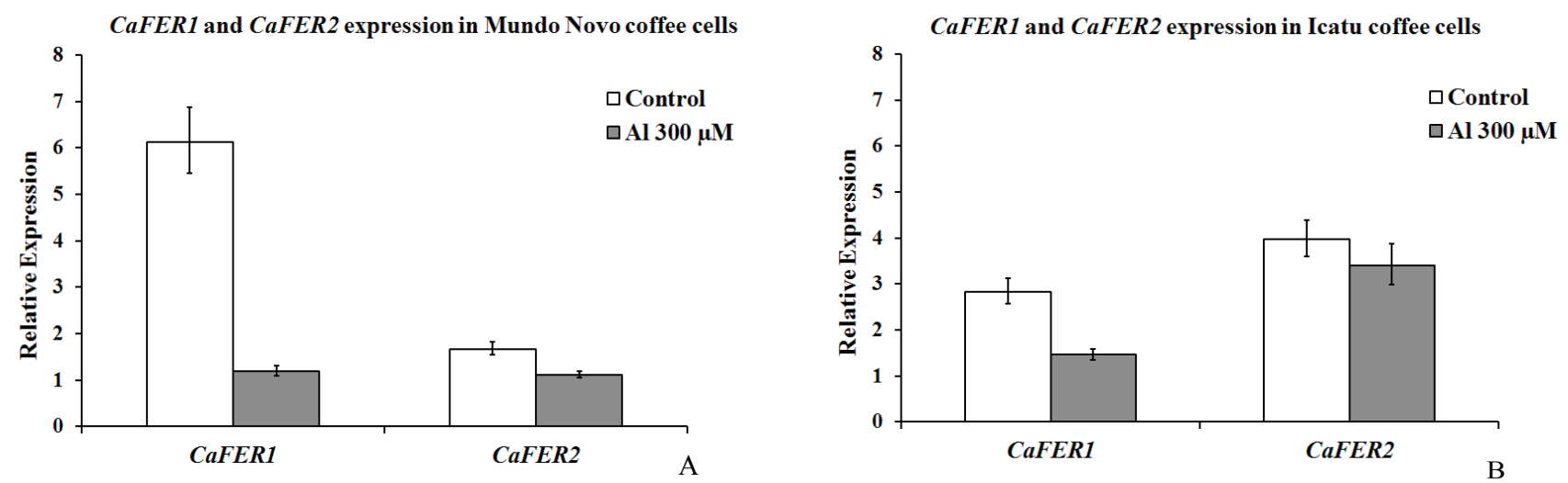

Figure 2. Quantitative PCR analysis of mRNA from the coffee ferritin genes CaFer1 and CaFer2 in Mundo Novo (A) and Icatu (B) varieties treated with $300 \mu \mathrm{M}$ Al compared to the constitutively expressed rpl39 gene. Columns represent gene expression average values obtained from three independent replicates and vertical bars indicate minimum and maximum relative expression values of three independent replicates.
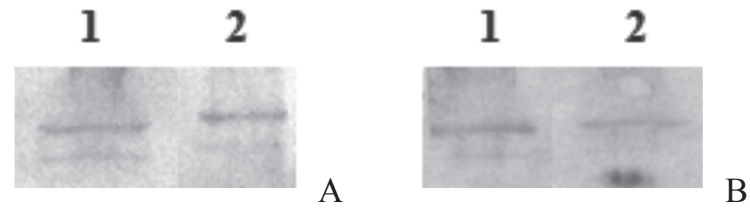

Figure 3. Western Blot analysis of ferritin protein in Mundo Novo (A) and Icatu (B) cells, using a polyclonal anti-ferritin antibody. All reactions were performed using $20 \mu \mathrm{g}$ of total protein extracts. Lane 1 - control; lane 2-300 $\mu \mathrm{M} \mathrm{Al}$.

varieties (figure 4). The CAT activity in Mundo Novo was responsive to the presence of the $\mathrm{Al}$, showing a 1.9-fold increase, while no variation was observed in the Icatu cells (figure 4A). The SOD activity assessed by non-denaturing PAGE revealed one major band whose activity was shown to increase in both coffee cells when treated with Al (figure 4B), but the response was more intense in the Mundo Novo cells. The total GR activity showed no significant increase in the Mundo Novo cells treated with Al, but in the Icatu cells, the activity increased by approximately 1.6-fold compared to the control cells (figure 4C). GPOX activity did not show significant variation in the Mundo Novo cells exposed to Al, while a 1.4-fold decrease was observed in the Icatu cells (figure 4D). GST levels increased in the cell suspensions of both varieties, exhibiting 1.6- and a 3.1-fold increases in the cells of Mundo Novo and Icatu, respectively (figure 4E).

\section{Discussion}

In alkaline, neutral or slightly acidic soils, Al exists in forms that are not harmful to plants, but at
$\mathrm{pH}<5.5$, it increases in solubility (as $\mathrm{Al}^{3+}$ speciation) and may be toxic to plants once it is taken up by the root cells, producing negative effects on plant growth and developmental processes (Goodwin \& Sutter 2009).

Root growth inhibition, reduction in water absorption and nutrient uptake (Delhaize \& Ryan 1995), ROS production and lipid peroxidation (Cakmak \& Horst 1991) are characteristic responses to Al stress. Even very low Al levels may cause significant metabolic responses in plants. Cucumber roots exposed to low levels of $\mathrm{Al}(1 \mu \mathrm{M}$ and $10 \mu \mathrm{M}$ of $\left.\mathrm{Al}_{2}\left(\mathrm{SO}_{4}\right)_{3}\right)$ at $\mathrm{pH} 4.0$ showed increased CAT and $\mathrm{SOD}$ activities and lipid peroxidation. Increased $\mathrm{H}_{2} \mathrm{O}_{2}$ levels were observed only after exposure to higher concentrations of Al (Pereira et al. 2010).

Martinez-Estevez et al. (2001b) performed a detailed study on the effects of $\mathrm{Al}$ on the growth of coffee cell suspensions. Initially, they determined the free $\mathrm{Al}$ concentration in the media at $\mathrm{pH} 4.3$ and 5.8 and found that at $25 \mu \mathrm{MAlCl}_{3}$, the metal concentration were approximately 17.3 and $7.8 \mu \mathrm{M}$, respectively. At the higher concentration tested $(100 \mu \mathrm{M})$, the values were 64.5 and $19.5 \mu \mathrm{M}$, respectively. The concentration of free $\mathrm{Al}$ was also determined for intermediate concentrations of $\mathrm{AlCl}_{3}(50$ and $75 \mu \mathrm{M})$. When $\mathrm{Al}$ was not included in the medium but the $\mathrm{pH}$ was kept at 4.3, cells grew more slowly than in the control, kept at pH 5.8. Next, Martinez-Estevez et al. (2001b) used pH 4.3 medium to study the Al toxicity of coffee cell cultures (in a 14 day culture cycle) exposed to a wide range of metal concentrations $\left(25-1,000 \mu \mathrm{MAlCl}_{3} \simeq 5.05-202 \mu \mathrm{M} \mathrm{Al}^{3+}\right)$ and observed 


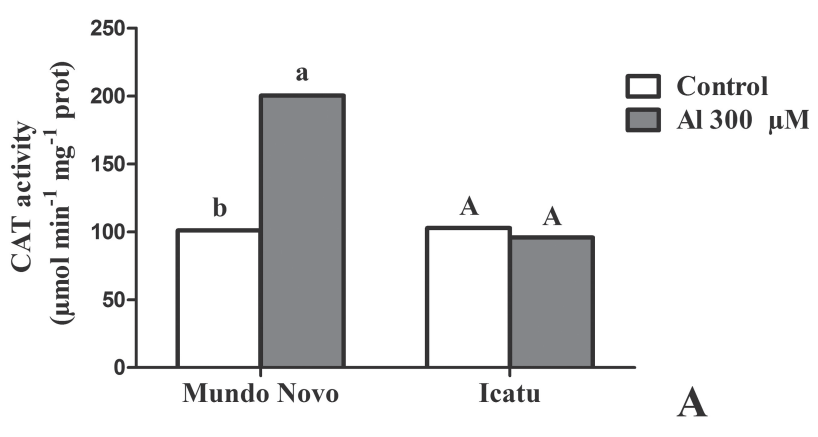

Mundo Novo

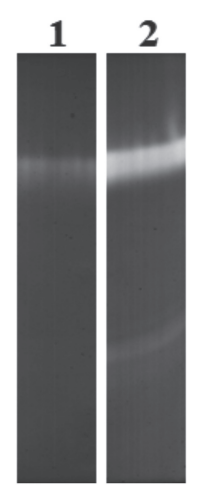

\section{Icatu}

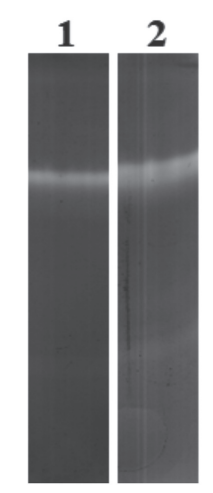

$\mathbf{B}$

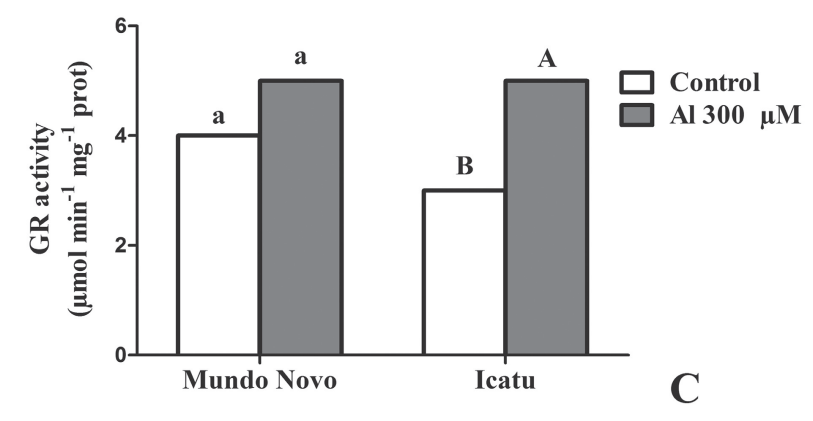

Figure 4. Specific activity of (A) catalase (CAT). Activity staining for (B) superoxide dismutase (SOD) following native PAGE of extracts of cultured coffee cells; lane 1, bovine SOD standard; lane 2, control (zero Al); lane 3, $72 \mathrm{~h}$ of growth in $300 \mu \mathrm{M}$ of Al. Specific activity of (C) glutathione reductase (GR); (D) guaiacol peroxidase GOPX and (E) glutathione S-transferase (GST) in coffee cells grown for a $72 \mathrm{~h}$ period in $300 \mu \mathrm{M}$ of Al. Means with the same letter are not significantly different $(p<0.05)$ by the Tukey's test.
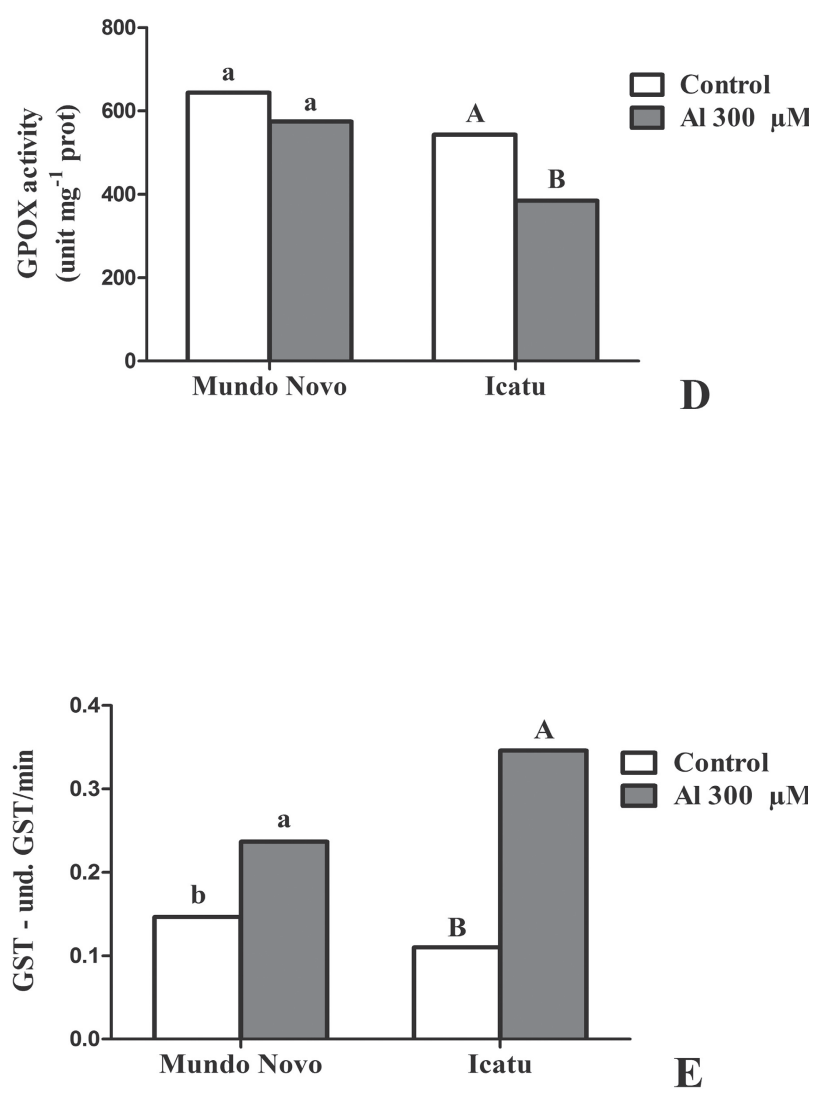

that cell growth diminished in a dose-responsive way, and the lethal dose (LD50) was found to be $25 \mu \mathrm{M}$ $\operatorname{AlCl} 3\left(5.05 \mu \mathrm{M} \mathrm{Al}^{3+}\right)$.

Here, we used $300 \mu \mathrm{M}$ of $\mathrm{Al}^{3+}$ and no visible alterations was observed indicating cell death, which was probably because the medium $\mathrm{pH}$ was set 5.8 and consequent low Al speciation. However, cells absorbed $\mathrm{Al}\left(4,350-4,500 \mathrm{mg} \mathrm{kg}^{-1}\right.$ cells, equivalent to $161-167 \mathrm{mM}$ ) and the concentration of $\mathrm{Al}^{3+}$ determined in the medium using the Geochem software was $4.35 \mu \mathrm{M} \mathrm{Al}^{3+}$, close to the LD50 observed by Martinez-Estevez et al. (2001b). Martinez-Estevez et al. (2001b) did not determine the Al concentration in the coffee cell suspension exposed to $25 \mu \mathrm{M}$ at $\mathrm{pH} 4.3$ but staining with the $\mathrm{Al}$ indicator dye Morin followed by UV-light observation showed a very intense Al concentration in the cells. Therefore, considering that cell suspensions provide better surface contact with the medium, it seems that $300 \mu \mathrm{M} \mathrm{Al}$ compensated for the low speciation as $\mathrm{Al}^{+3}$ caused by the $5.8 \mathrm{pH}$ level.

Despite the alterations in the enzyme activities 
observed here, it was not possible to detect any difference in TBARS concentrations (figure 1), a typical sign of Al toxicity in plants indicating membrane lipid peroxidation. A similar situation was already observed in coffee cell suspensions exposed to $\mathrm{Ni}$ (Gomes-Junior et al. 2006a) and $\mathrm{Cd}$ (Gomes-Junior et al. 2006b). While at high metal concentrations (305 $\mu \mathrm{M} \mathrm{Cd}$ and $225 \mu \mathrm{M} \mathrm{Ni}$ ) there was a significant increase in TBARS, at low metal concentration $(30.5 \mu \mathrm{M}$ Cd and $22.5 \mu \mathrm{M} \mathrm{Ni})$ TBARS levels remained low, although changes were observed in antioxidant enzyme activities. According to Gomes-Junior et al. (2006a, 2006b), the oxidative stress tolerance at low $\mathrm{Cd}$ and $\mathrm{Ni}$ concentrations indicated by unaltered TBARS values may be due to a rapid and significant increase in the activities of some of the major antioxidant enzymes, such as APX, CAT, SOD and GR, suggesting therefore an effective protection.

Besides a role as a putative Fe-storage protein, studies on plant ferritin functions have indicated a probable link between this protein and protection against oxidative stress (Briat et al. 2010b). Ferritin in animals has also been documented to bind $\mathrm{Al}$ atoms, which might be a cellular protection mechanism, guarding against eventual accumulated oxidative damage (Sakamoto et al. 2004). The reports with animals exhibited results indicating that the number of Al atoms can vary from 10 to 160 per ferritin molecule (Briat \& Lebrun 1999).

Several recent reports have described the potential of ferritin to act as a cytoprotective antioxidant, which suggests that in addition to being an important $\mathrm{Fe}$ source for plant nutrition and maintaining $\mathrm{Fe}$ homeostasis, this protein also plays relevant roles in plant defence against oxidative stress. The close interaction between Fe homeostasis and ROS has been well-characterised in bacteria and animals, in which the regulation of Fe homeostasis has been shown to be modulated by oxidative stress (Ravet et al. 2009).

A possible role for coffee ferritin involving response against oxidative stress provoked by $\mathrm{Al}$ was excluded because in both coffee varieties, ferritin expression decreased (figures 2A and 2B). We also did not observe any accumulation of the ferritin protein in Al-stressed cells; instead, we observed a decrease in Icatu (figure 3). On the other hand, ferritin gene expression increased as a response to high level of $\mathrm{Fe}$ in coffee cell cultures (Bottcher et al. 2011).

It is known that metals induce oxidative stress, and the involvement of $\mathrm{Al}$ in this type of plant response has been previously suggested, even though Al itself is not a transition metal and cannot catalyze redox reactions (Yamamoto et al. 2002, Vitorello et al. 2005). It has also been shown that low concentrations of $\mathrm{Al}$ are sufficient to generate ROS and provoke oxidative stress in plants (Richards et al. 1998, Yamamoto et al. 2002). We have analysed the responses of key antioxidant enzymes that have been previously shown to respond to metal-induced oxidative stress in plants (Gratão et al. 2005). SOD activity is responsible for the degradation of the superoxide radical $\left(\mathrm{O}_{2}{ }^{\circ}\right)$, producing $\mathrm{O}_{2}$ and $\mathrm{H}_{2} \mathrm{O}_{2}$. Here, total SOD activity on non-denaturing PAGE showed an increased activity for both coffee varieties (figure 4B), indicating that $\mathrm{Al}$ exposure induces the formation of $\mathrm{O}_{2}{ }^{--}$in a quantity greater than that which the pre-existing SOD can remove (Boscolo et al. 2003). Al was shown to enhance SOD mRNA levels in the root tips of Arabidopsis (Richards et al. 1998), the roots and shoots of rice seedlings (Sharma \& Dubey 2007) and the roots of sorghum (Peixoto et al. 1999).

Unfortunately we did not measure the activity of ascorbate peroxidase (E.C. 1.11.1.11), the main $\mathrm{H}_{2} \mathrm{O}_{2}$ scavenging in plant cells. Less effectively, CAT is also responsible for the degradation of hydrogen peroxide $\left(\mathrm{H}_{2} \mathrm{O}_{2}\right)$. The increase in CAT activity suggests the existence of elevated Al-enhanced $\mathrm{H}_{2} \mathrm{O}_{2}$ production in suspension cells, but this increase was observed only in Mundo Novo, remaining unaltered in Icatu cells exposed to Al (figure 4A). CAT activity was also inhibited significantly in the root cells of Allium cepa L. exposed to Al (Achary et al. 2008). In Al-stressed rice seedlings, CAT did not appear to be an efficient scavenger of $\mathrm{H}_{2} \mathrm{O}_{2}$ when higher concentrations of this metal were used (Ma et al. 2007, Sharma \& Dubey 2007). CAT, SOD, and APX are important ROS-scavenging enzymes in plants. The balance among these enzymes is crucial for determining the steady-state level of superoxide radicals and hydrogen peroxide (Pereira et al. 2011).

The enzyme GPOX participates in different metabolic reactions, such as lignin biosynthesis, cell wall cross-linkage, auxin degradation, disease resistance, oxidative stress and converting $\mathrm{H}_{2} \mathrm{O}_{2}$ to water (Gratão et al. 2005). There was no increase observed in GPOX activity in the cells of Mundo Novo; however, a decrease was observed in Icatu (figure 4D). These results might indicate that $\mathrm{H}_{2} \mathrm{O}_{2}$ degradation occurred in Mundo Novo mainly due to 
the activation of CAT, while the activities of other peroxidases are involved in $\mathrm{H}_{2} \mathrm{O}_{2}$ detoxification in Icatu. For instance, other enzymes, such as GR (figure 4C) and GST (figure 4E) have both exhibited significantly increased activities in response to $\mathrm{Al}$ in Icatu. The increased GST activity was also observed for Mundo Novo; however, it was not to the same extent, whereas changes in GR activities in Mundo Novo were not significantly different between the $\mathrm{Al}$ and control treatments. GST enzymes conjugate a co-substrate that contains a reactive electrophilic centre to glutathione in the reduced form (GSH) and form S-glutathionylated reaction products that are transported to the vacuole, detoxifying toxic substances (Kumari et al. 2008). These enzymes help to protect cells from oxidative stress. GST has been observed to be upregulated in Arabidopsis and rice that have been exposed to Al (Ezaki et al. 2004, Yang et al. 2007). The GR and GST results clearly indicate that $\mathrm{Al}$ is inducing the enhanced activities of the enzymes, which is occurring more dramatically in Icatu. The increased GR activity in Icatu also indicates the need to maintain glutathione in the reduced form, providing a favourable redox status to avoid the oxidative damage of the cells (Gomes-Junior et al. 2006a, Sharma \& Dubey 2007).

The differences observed between Mundo Novo and Icatu with regard to ferritin expression and enzyme activities may be related to their genetic backgrounds. The Icatu lineage used here is an advanced generation of a hybrid between $C$. arabica and C. canephora that was backcrossed six times with the former until the agronomical and beverage quality attributes had been rescued. Icatu inherited its resistance to the leaf coffee rust from C. canephora, which is caused by Hemileia vastatrix Berk et Br. (Carvalho 1988). While $C$. arabica is tetraploid $(2 n=44)$ and is found in the storey of Ethiopian forests, $C$. canephora is diploid and, among Coffea species, it has the widest natural distribution area in tropical African forests (Gomez et al. 2009). To hybridise the two species, chromosomes in C. canephora were duplicated using colchicine (Monaco et al. 1975). In comparison with Catuaí, a dwarf $C$. arabica variety resulting from a cross between Mundo Novo and the dwarf variety Caturra, Icatu seedlings that had been slowly acclimated to cold showed the greatest ability to control oxidative stress damage by enhancing enzyme activities ( $\mathrm{Cu}, \mathrm{Zn}-\mathrm{SOD}$ and ascorbate peroxidase), increasing the contents of antioxidant molecules (ascorbate, alpha-tocopherol and chlorogenic acids), lowering the reactive oxygen species contents $\left(\mathrm{H}_{2} \mathrm{O}_{2}\right.$ and $\mathrm{OH}^{\circ}$ ) and also increasing the expression of genes coding for GR, dihydroxy ascorbate reductase and class III and IV chitinases (Fortunato et al. 2010).

Therefore, our results suggest that the ability of coffee cells to support low Al concentrations seems to be related to its capacity to switch on antioxidant defences. Additionally, both varieties studied here showed differential responses, providing evidence that the induction or inhibition of specific antioxidant enzymes in response to $\mathrm{Al}$ is variety-dependent. Finally, these results indicate that ferritin may not be involved in the prevention of oxidative stress damage provoked by $\mathrm{Al}$ excess in coffee cell suspensions.

\section{Acknowledgments}

The authors are grateful to Dr. Janette Palma Fett (Universidade Federal do Rio Grande do Sul) for providing the polyclonal anti-ferritin antibody used in this study. This work was supported by grants from Fundação de Amparo à Pesquisa do Estado de São Paulo (FAPESP) and Conselho Nacional de Desenvolvimento Científico e Tecnológico - Brasil (CNPq).

\section{References}

Achary, V.M.M., Jena, S., Panda, K.K. \& Panda, B.B. 2008. Aluminium induced oxidative stress and DNA damage in root cells of Allium cepa L. Ecotoxicology and Environmental Safety 70: 300-310.

Ayres, M., Ayres Jr. M., Jr. Ayres, D.L. \& Santos, A.S. 2003. BioEstat 3.0: Aplicações Estatísticas nas Áreas das Ciências Biológicas e Médicas. Sociedade Civil Mamirauá, Belém.

Azevedo, R.A., Alas, R.M., Smith, R.J. \& Lea, P.J. 1998. Response of antioxidant enzymes to transfer from elevated carbon dioxide to air and ozone fumigation, in the leaves and roots of wild-type and a catalase-deficient mutant of barley. Physiologia Plantarum 104: 280-292.

Boscolo, P.R.S., Menossi, M. \& Jorge, R.A. 2003. Aluminum-induced oxidative stress in maize. Phytochemistry 62: 181-189.

Bottcher, A., Nobile, P., Martins, P., Conte, F., Azevedo, R. \& Mazzafera, P. 2011. A role for ferritin in the antioxidant system in coffee cell cultures. Biometals 24: 225-237.

Braccini, M.C.L., Martinez, H.E.P., Braccini, A.L. \& Mendonça, S.M. 2000. Avaliação do pH da rizosfera de genótipos de café em resposta à toxidez de alumínio no solo. Bragantia 59: 83-88. 
Braccini, M.C.L., Martinez, H.E.P., Pereira, P.R.G., Sampaio, N.F. \& Silva, E.A.M. 1998. Tolerância de genótipos de cafeeiro ao alumínio em solução nutritiva. I. Crescimento e desenvolvimento da parte aérea e sistema radicular. RevistaBrasileira de Ciência do Solo 22:435-442.

Bradford, M.M. 1976. Rapid and sensitive method for quantitation of microgram quantities of protein utilizing principle of protein-dye binding. Analytical Biochemistry 72: 248-254.

Briat, J.F., Duc, C., Ravet, K. \& Gaymard, F. 2010a. Ferritins and iron storage in plants. Biochimica et Biophysica Acta - General Subjects 1800: 806-814.

Briat, J.F. \& Lebrun, M. 1999. Plant responses to metal toxicity. Comptes Rendus de l'Académie des Sciences Series III - Sciences de la Vie-Life Sciences 322: 43-54.

Briat, J.F., Ravet, K., Arnaud, N., Duc, C., Boucherez, J., Touraine, B., Cellier, F. \& Gaymard, F. 2010b. New insights into ferritin synthesis and function highlight a link between iron homeostasis and oxidative stress in plants. Annals of Botany 105: 811-822.

Cairo, G., Tacchini, L., Pogliaghi, G., Anzon, E., Tomasi, A. \& Bernelli-Zazzera, A. 1995. Induction of ferritin synthesis by oxidative stress. Journal of Biological Chemistry 270: 700-703.

Cakmak, I. \& Horst, W.J. 1991. Effect of aluminium on lipid peroxidation, superoxide dismutase, catalase, and peroxidase activities in root tips of soybean (Glycine max). Physiologia Plantarum 83: 463-468.

Carvalho, A. 1988. Principles and practices of coffee plant breeding for productivity and quality factors: Coffea arabica. In: R.J. Clarke \& R. Macrae (eds.) Cofee. Elsevier, London, pp. 129-165.

Chen, L.S., Qi, Y.P., Jiang, H.X., Yang, L.T. \& Yang, G.H. 2010. Photosynthesis and photoprotective systems of plants in response to aluminum toxicity. African Journal of Biotechnology 9: 9237-9247.

Déak, M., Horváth, G.V., Davletova, S., Török, K., Sass, L., Vass, I., Barna, B., Király, Z. \& Dudits, D. 1999. Plants ectopically expressing the iron-binding protein, ferritin, are tolerant to oxidative damage and pathogens Nature Biotechnology 17: 192-196.

Delhaize, E. \& Ryan, P.R. 1995. Aluminum toxicity and tolerance in plants. Plant Physiology 107: 315-321.

Ezaki, B., Katsuhara, M., Kawamura, M. \& Matsumoto, H. 2001. Different mechanisms of four aluminum (Al)-resistant transgenes for $\mathrm{Al}$ toxicity in Arabidopsis. Plant Physiology 127: 918-927.

Ezaki, B., Suzuki, M., Motoda, H., Kawamura, M., Nakashima, S. \& Matsumoto, H. 2004. Mechanism of gene expression of Arabidopsis glutathione S-transferase, AtGST1, and AtGST11 in response to aluminum stress. Plant Physiology 134: 1672-1682.

Ezaki, B., Tsugita, S. \& Matsumoto, H. 1996. Expression of a moderately anionic peroxidase is induced by aluminum treatment in tobacco cells: Possible involvement of peroxidase isozymes in aluminum ion stress. Physiologia Plantarum 96: 21-28.
Filippi,S.B.,Azevedo, R.A.,Sodek,L.\& Mazzafera,P. 2007. Allantoin has a limited role as nitrogen source in cultured coffee cells. Journal of Plant Physiology 164: 544-552.

Fortunato, A.S., Lidon, F.C., Batista-Santos, P., Leitão, A.E., Pais, I.P., Ribeiro, A.I. \& Ramalho, J.C. 2010. Biochemical and molecular characterization of the antioxidative system of Coffea $\mathrm{sp}$. under cold conditions in genotypes with contrasting tolerance. Journal of Plant Physiology 167: 333-342.

Gomes-Junior, R.A., Moldes, C.A., Delite, F.S., Gratão, P.L., Mazzafera, P., Lea, P.J. \& Azevedo, R.A. 2006a. Nickel elicits a fast antioxidant response in Coffea arabica cells. Plant Physiology and Biochemistry 44: 420-429.

Gomes-Junior, R.A., Moldes, C.A., Delite, F.S., Pompeu, G.B., Gratão, P.L., Mazzafera, P., Lea, P.J. \& Azevedo, R.A. 2006b. Antioxidant metabolism of coffee cell suspension cultures in response to cadmium. Chemosphere 65: 1330-1337.

Gomez, C., Dussert, S., Hamon, P., Hamon, S., Kochko, A. \& Poncet, V. 2009. Current genetic differentiation of Coffea canephora Pierre ex A. Froehn in the Guineo-Congolian African zone: cumulative impact of ancient climatic changes and recent human activities. BMC Evolutionary Biology 9: 167.

Goodwin, S.B. \& Sutter, T.R. 2009. Microarray analysis of Arabidopsis genome response to aluminum stress. Biologia Plantarum 53: 85-99.

Gratão, P.L., Polle, A., Lea, P.J. \& Azevedo, R.A. 2005. Making the life of heavy metal-stressed plants a little easier. Functional Plant Biology 32: 481-494.

Habig,W.H.\& Jakoby, W.B. 1981. Glutathione S-transferases (rat and human). Methods in Enzymology 77: 218-231.

Haridasan, M. 2008. Nutritional adaptations of native plants of the cerrado biome in acid soils. Brazilian Journal of Plant Physiology 20: 183-195.

Kochian, L.V., Pence, N.S., Letham, D.L.D., Pineros, M.A., Magalhaes, J.V., Hoekenga, O.A. \& Garvin, D.F. 2002. Mechanisms of metal resistance in plants: aluminum and heavy metals. Plant and Soil 247: 109-119.

Kumari, M., Taylor, G.J. \& Deyholos, M.K. 2008. Transcriptomic responses to aluminum stress in roots of Arabidopsis thaliana. Molecular Genetics and Genomics 279: 339-357.

Livak, K.J. \& Schmittgen, T.D. 2001. Analysis of relative gene expression data using real-time quantitative PCR and the 2(T)(-Delta Delta C) method. Methods 25: 402-408.

Ma, B.H., Wan, J.M. \& Shen, Z.G. 2007. $\mathrm{H}_{2} \mathrm{O}_{2}$ production and antioxidant responses in seeds and early seedlings of two different rice varieties exposed to aluminum. Plant Growth Regulation 52: 91-100.

Martinez-Estevez, M., Loyola-Vargas, V.M. \& Hernandez-Sotomayor, S.M.T. 2001a. Aluminum increases phosphorylation of particular proteins in cellular suspension cultures of coffee (Coffea arabica). Journal of Plant Physiology 158: 1375-1379. 
Martinez-Estevez, M., Munoz-Sanchez, J.A., Loyola-Vargas, V.M. \& Hernandez-Sotomayor, S.M.T. 2001b. Modification of the culture medium to produce aluminum toxicity in cell suspensions of coffee (Coffea arabica L.). Plant Cell Reports 20: 469-474.

Monaco, L.C., Sondahl, M.R. \& Carvalho, A. 1975. New technique for colchinice treatment of coffee seedlings. Turrialba 25: 323-324.

Murashige, T. \& Skoog, F. 1962. A revised medium for rapid growth and bio assays with tobacco tissue cultures. Physiologia Plantarum 15: 473-497.

Neuenschwander, B. \& Baumann, T.W. 1992. A novel type of somatic embryogenesis in Coffea arabica. Plant Cell Reports 10: 608-612.

Oliveira, A.A.S., Gomes, M.F.M., Santos, J., Rufino, L., Silva Júnior, A.G. \& Gomes, S.T. 2008. Estrutura e dinâmica da cafeicultura em Minas Gerais. Revista de Economia 34: 121-142.

Panda, S. \& Matsumoto, H. 2010. Changes in antioxidant gene expression and induction of oxidative stress in pea (Pisum sativum L.) under Al stress. BioMetals 23: 753-762.

Pavan, M.A. \& Bingham, F.T. 1982. Toxicity of aluminum to coffee seedlings grown in nutrient solution. Soil Science Society of American Journal 46: 993-997.

Peixoto, P.H.P., Cambraia, J., Sant'Anna, R., Mosquim, P.R. \& Moreira, M.A. 1999. Aluminum effects on lipid peroxidation and on the activities of enzymes of oxidative metabolism in sorghum. Revista Brasileira de Fisiologia Vegetal 11: 137-143.

Pereira, L.B. Mazzanti, C.M.A., Cargnelutti, D., Rossato, L., Gonçalves, J.F., Calgaroto, N., Dressler, V., Nicoloso, F., Federizzi, L., Morsch, V.M. \& Schetinger, M.R. 2011. Differential responses of oat genotypes: oxidative stress provoked by aluminum. BioMetals 24: 73-83.

Pereira, L.B., Mazzanti, C.M.A., Gonçalves, J.F., Cargnelutti, D., Tabaldi, L.A., Becker, A.G., Calgaroto, N.S., Farias, J.G., Battisti, V., Bohrer, D. Nicoloso, F.T., Morsch, V.M. \& Schetinger, M.R. 2010. Aluminum-induced oxidative stress in cucumber. Plant Physiology and Biochemistry 48: 683-689.

Pinheiro, H.A., DaMatta, F.M., Chaves, A.R.M., Fontes, E.P.B. \& Loureiro, M.E. 2004. Drought tolerance in relation to protection against oxidative stress in clones of Coffea canephora subjected to long-term drought. Plant Science 167: 1307-1314.

Ponte, L.M.E. \& Valencia, A.G. 1983. Toxicidade de alumínio en plantas de café. Cenicafé 34: 61-97.

Ramírez-Benítez, J.E., Chee-González, L. \& Hernandez-Sotomayor, S.M.T. 2008. Aluminium induces changes in organic acids metabolism in Coffea arabica suspension cells with differential Al-tolerance. Journal of Inorganic Biochemistry 102: 1631-1637.
Ramírez-Benítez, J.E., Hernández-Sotomayor, S.M.T. \& Muñoz-Sánchez, J.A. 2009. The location of aluminium in protoplasts and suspension cells taken from Coffea arabica L. with different tolerance of Al. Journal of Inorganic Biochemistry 103: 1491-1496.

Ravet, K., Touraine, B., Boucherez, J., Briat, J.F., Gaymard, F. \& Cellier, F. 2009. Ferritins control interaction between iron homeostasis and oxidative stress in Arabidopsis. Plant Journal 57: 400-412.

Richards, K.D., Schott, E.J., Sharma, Y.K., Davis, K.R. \& Gardner, R.C. 1998. Aluminum induces oxidative stress genes in Arabidopsis thaliana. Plant Physiology 116: 409-418.

Rodrigues, L.A., Martinez, H.E.P., Neves, J.C.L., Novais, R.F. \& Mendonca, S.M. 2011. Growth response of coffee tree shoots and roots to subsurface liming. Plant and Soil 234: 207-214.

Sakamoto, T., Ogasawara, Y., Ishii, K., Takahashi, H. \& Tanabe, S. 2004. Accumulation of aluminum in ferritin isolated from rat brain. Neuroscience Letters 366:264-267.

Scandalios, J.G. 2005. Oxidative stress: molecular perception and transduction of signals triggering antioxidant gene defenses. Brazilian Journal of Medical and Biological Research 38: 995-1014.

Sharma, P. \& Dubey, R.S. 2007. Involvement of oxidative stress and role of antioxidative defense system in growing rice seedlings exposed to toxic concentrations of aluminum. Plant Cell Reports 26: 2027-2038.

Simonovicova,M., Tamas,L., Huttova,J. \& Mistrik, I. 2004. Effect of aluminium on oxidative stress related enzymes activities in barley roots. Biologia Plantarum 48: 261-266.

Strozycki, P.M., Skpska, A., SzczeBniak, K., Sobieszczuk, E., Briat, J.-F. \& Legocki, A.B. 2003. Differential expression and evolutionary analysis of the three ferritin genes in the legume plant Lupinus luteus. Physiologia Plantarum 118: 380-389.

Vile, G.F. \& Tyrrell, R.M. 1993. Oxidative stress resulting from ultraviolet A irradiation of human skin fibroblasts leads to a heme oxygenase-dependent increase in ferritin. Journal of Biological Chemistry 268: 14678-14681.

Vitorello, V.A., Capaldi, F.R.\& Stefanuto, V.A. 2005. Recent advances in aluminum toxicity and resistance in higher plants. Brazilian Journal of Plant Physiology 17: 129-143.

Yamamoto, Y., Kobayashi, Y., Devi, S.R., Rikiishi, S. \& Matsumoto, H. 2002. Aluminum toxicity is associated with mitochondrial dysfunction and the production of reactive oxygen species in plant cells. Plant Physiology 128: 63-72.

Yamamoto, Y., Kobayashi, Y., Devi, S.R., Rikiishi, S. \& Matsumoto, H. 2003. Oxidative stress triggered by aluminum in plant roots. Plant and Soil 255: 239-243.

Yang, Q.S., Wang, Y.Q., Zhang, J.J., Shi, W.P., Qian, C.M. \& Peng, X.X. 2007. Identification of aluminumresponsive proteins in rice roots by a proteomic approach: Cysteine synthase as a key player in $\mathrm{Al}$ response. Proteomics 7: 737-749. 